Abstracta Iranicacta Iranica

Revue bibliographique pour le domaine irano-aryen

Volume 30 | 2010

Comptes rendus des publications de 2007

\title{
Drugs in Afghanistan: opium, outlaws and scorpion tales. London, Pluto, 2007, 320 p.
}

\section{Anicée Van Engeland}

\section{(2) OpenEdition}

1 Journals

\section{Édition électronique}

URL : http://journals.openedition.org/abstractairanica/38076

DOI : 10.4000/abstractairanica.38076

ISSN : 1961-960X

Éditeur :

CNRS (UMR 7528 Mondes iraniens et indiens), Éditions de l'IFRI

\section{Édition imprimée}

Date de publication : 8 avril 2010

ISSN : 0240-8910

\section{Référence électronique}

Anicée Van Engeland, «Drugs in Afghanistan: opium, outlaws and scorpion tales. London, Pluto, 2007, 320 p. », Abstracta Iranica [En ligne], Volume 30 | 2010, document 294, mis en ligne le 08 avril 2010, consulté le 26 septembre 2020. URL : http://journals.openedition.org/abstractairanica/38076 ; DOI : https://doi.org/10.4000/abstractairanica.38076

Ce document a été généré automatiquement le 26 septembre 2020.

Tous droits réservés 


\title{
Drugs in Afghanistan: opium, outlaws and scorpion tales. London, Pluto, 2007, $320 \mathrm{p}$.
}

\author{
Anicée Van Engeland
}

L'Afghanistan est un des plus gros producteurs de drogue. Le peuple afghan est devenu la victime de la production, du trafic et de l'utilisation de ces drogues. L'A. mène une enquête approfondie sur les filières et méthodes de production, le matraquage des paysans, le trafic et la propagation de l'héroïne dans le pays. Il réfute aussi la thèse de la transformation de la culture de l'opium en culture de drogues à usage pharmaceutique car ce type de commerce rendrait l'Afghanistan dépendant de ses voisins.

\section{INDEX}

Thèmes : 12.2. Afghanistan

\section{AUTEURS}

ANICÉE VAN ENGELAND

European University Institute - Florence 